\title{
Assessment of entomopathogenic nematodes in Agrotis ipsilon (Lepidoptera: Noctuidae) under laboratory and greenhouse conditions
}

\author{
Evaluación de nematodos entomopatógenos en Agrotis ipsilon (Lepidoptera: Noctuidae) \\ bajo condiciones de laboratorio e invernadero \\ ANDRÉIA DE OLIVEIRA GIANNASI ${ }^{1,2}$, CAMILA ROQUE BRAMBILA $^{1,3}$, MARCELO ZART $^{1,4}$, \\ BRUNA APARECIDA GUIDE 5 and VIVIANE SANDRA ALVES ${ }^{1,6}$
}

\begin{abstract}
This work aims to evaluate the potential of Brazilian isolates of entomopathogenic nematodes through the selection of isolates for Agrotis ipsilon (Hufnagel) (Lepidoptera: Noctuidae). In order to analyze the susceptibility at different instars of the insect and different concentrations, to investigate the in vivo production of these isolates, and to perform greenhouse tests in the Laboratory of Entomologia e Controle Microbiano of Universidade Estadual do Norte do Paraná, Brazil. Selection tests were carried out with nine isolates, and those that caused greater percentages of insect mortality were used in concentration tests $\left(0,50,100,150,200\right.$ Infective Juveniles (IJs) $\left./ \mathrm{cm}^{2}\right)$, with different instars of the insect $\left(2^{\text {nd }}, 3^{\text {rd }}, 4^{\text {th }}, 5^{\text {th }}, 6^{\text {th }}\right.$ instars and pupa), in the in vivo production of $A$. ipsilon larvae, and in pathogenicity tests in a greenhouse. In the selection test, the isolate $\mathrm{CH} 3$ (Steinernema sp.) caused $100 \%$ of mortality in A. ipsilon, and the isolates GL (Heterorhabditis amazonensis), IBCBn-02 (S. carpocapsae) and IBCB-n05 (H. indica) caused $90 \%$ mortality. In the tests of different concentrations, the isolate IBCB-n02 had $\mathrm{CL}_{99}$ estimated at a concentration of $140 \mathrm{IJ} /$ $\mathrm{cm}^{2}$, and the isolate IBCB-n05 had $\mathrm{CL}_{99}$ estimated at a concentration of $190 \mathrm{IJ} / \mathrm{cm}^{2}$. The most susceptible larval stages were the $3^{\text {rd }}$ and $4^{\text {th }}$ instars. In the in vivo test for production of $A$. ipsilon larvae, no difference was observed between the two isolates. In the greenhouse test, the isolate IBCB-n02 was the only one that differed from the control treatment.
\end{abstract}

Key words: Cutworm, corn, biological control.

Resumen: El objetivo de este trabajo fue evaluar el potencial de los nematodos entomopatógenos (NEPs) de los géneros Steinernema y Heterorhabditis en el control de Agrotis ipsilon (Hufnagel) (Lepidoptera: Noctuidae). Para esto, se realizaron ensayos de selección de aislamientos, se evaluó la susceptibilidad en diferentes instares del insecto, se analizaron las diferentes concentraciones de NEPs y la producción in vivo de estos aislados, y se realizaron pruebas en invernadero en el Laboratorio de Entomología y control biológico de la Universidade Estadual do Norte do Paraná, Brasil. En los ensayos de selección con nueve aislamientos, los que causan mayor porcentaje de mortalidad en los insectos, se utilizaron diferentes concentraciones $\left(0,50,100,150,200\right.$ Juveniles Infectivos $\left./ \mathrm{cm}^{2}\right)$ sobre diferentes instares del insecto $\left(2^{\text {do }}, 3^{\text {er }}, 4^{\text {to }}, 5^{\text {to }}, 6^{\text {to }}\right.$ instar y pupa), en la producción in vivo en larvas de $A$. ipsilon y en pruebas de patogenicidad en invernadero. En el ensayo de selección, el aislamiento CH3 (Steinernema sp.) causó el $100 \%$ de la mortalidad en A. ipsilon mientras que los aislados GL (Heterorhabditis amazonensis), IBCB-n02 (S. carpocapsae) e IBCB-n05 (H. indica) causaron $90 \%$ de mortalidad. En la prueba de concentraciones, el aislado IBCB-n02 presentó una $\mathrm{CL}_{99}$ de $140 \mathrm{IJs} / \mathrm{cm}^{2}$ y el aislado IBCB-n05, una $\mathrm{CL}_{99}$ de $190 \mathrm{IJs} / \mathrm{cm}^{2}$. Las larvas de $3^{\text {er }}$ y $4^{\text {to }}$ instares fueron más susceptibles. En la prueba in vivo para la producción de larvas de A. ipsilon, no se observó diferencia entre los dos aislamientos. En el ensayo en invernadero, el aislado IBCB-n02 fue el único que difirió del tratamiento de control.

Palabras clave: Larva de polilla, maíz, control biológico.

\section{Introduction}

The black cutworm Agrotis ipsilon (Hufnagel, 1767) (Lepidoptera: Noctuidae) is a polyphagous pest that feeds on nearly all varieties of vegetables and many important grains, attacking mainly Solanaceae, Cruciferae and Curcubitaceae; however, they can also attack other species of different plant families, such as corn and soybeans (Link and Pedrolo 1987; Fernandes et al. 2013). This pest is a nocturnal insect, and when the larvae are touched, they roll up, becoming threadlike in appearance. During the day, the insect remains buried in the ground, which hinders its viewing field and consequently its control (Bento et al. 2007). In corn crop, younger larvae damage the leaves, and from the $3^{\text {rd }}$ and $4^{\text {th }}$ instars, they cut the base of the stem, causing streaks on the leaves, and the appearance of cuts in the seedlings at the base of the stem, resulting in losses of up to $27 \%$ (Salvadori 2011).
The control of the black cutworm becomes difficult due to the insect's habits. Nevertheless, studies have reported the use of allelochemicals to inhibit the growth of larval stages (Reese and Beck 1976). In relation to the biological control, the presence of parasitoids and predators in the field and the consequent reduction in the insect population was reported by Link and Costa (1984). The use of Bacillus thuringiensis in the laboratory (Menezes et al. 2010) and in the field, by means of transgenic plants (Kullik et al. 2011), as well as the use of Baculovirus (Prater et al. 2006) have also been reported.

Entomopathogenic nematodes (EPNs) are insect parasites, which insecticide activity is given by a symbiosis with bacteria (Xenorhabdus and Photorhabdus), leading the host to death. This is one of the reasons of the successful microbial control (Grewal et al. 2001; Lewis et al. 2006). Infective juveniles (IJs) invade the body of their

\footnotetext{
${ }^{1}$ Universidade Estadual do Norte do Paraná, Av. Portugal, n. 340, Centro, CEP 86300-000, Cornélio Procópio, Paraná, Brazil. ${ }^{2}$ Agronomist. M. Sc., Universidade Estadual do Norte do Paraná, Cornélio Procópio, Paraná, Brazil, deiauenp@gmail.com. ${ }^{3}$ Biologist, Universidade Estadual do Norte do Paraná, Cornélio Procópio, Paraná, Brazil, camilabuenp@gmail.com. ${ }^{4}$ Doctor in Agronomy, Universidade Estadual do Norte do Paraná, Cornélio Procópio, Paraná, Brazil, marcelo_zart@yahoo.com.br. ${ }^{5}$ Ph. D. Student in Agronomy, Universidade Estadual de Londrina, Rodovia Celso Garcia Cid, Pr 445 Km 380. Cx. Postal 10.011. Londrina, Brazil. 86.057-970. bruhguide@gmail.com. ${ }^{6}$ Pos-Doctor in Sciences, Universidade Estadual do Norte do Paraná, Cornélio Procópio, Paraná, Brazil, vivialves@uenp.edu.br. Corresponding author: Viviane Sandra Alves. Pos-Doctor in Sciences, Universidade Estadual do Norte do Paraná, Av. Portugal, n. 340, Centro, CEP 86300-000, Cornélio Procópio, Paraná, Brazil, vivialves@uenp.edu.br.
} 
hosts and release their bacteria at the hemolymph stage, causing fast death of the insect by septicemia. Afterwards, the EPNs feed digested tissues of the dead insect and of the bacteria and reproduce themselves in several generations. When the food is depleted, the IJs leave the host searching for new hosts (Poinar 1990; Ferraz 1998).

EPNs present great tolerance to variations in environmental conditions. They can be used in combination with other control techniques, including chemical control, and are more recommended for the control of insect pests that present cryptic habitats associated with soil, since the nematodes can move themselves searching for a host (Ferraz 1998; Toledo et al. 2010).

Studies on EPNs are recent in Brazil. In the last few years, some works developed in the laboratory have demonstrated the potential of these agents to control several pests (Machado et al. 2005; Alves et al. 2009; Alves et al. 2012; Bortoluzzi et al. 2013). For instance, Leite et al. (2005), Andaló et al. (2010), and Andaló et al. (2012) studied insects of the order Lepidoptera, but there are no studies with Brazilian isolates aimed the control of $A$. ipsilon.

Thus, this work aims to evaluate the potential of Brazilian isolates of entomopathogenic nematodes by means of selection of isolates for $A$. ipsilon; to analyze the susceptibility at different instars of the insect and different concentrations; to investigate the in vivo production of these isolates; and to perform greenhouse tests.

\section{Materials and methods}

Entomopathogenic nematodes isolates. The EPNs isolates used in this work were obtained by the Universidade Federal de Lavras (UFLA), MG, Embrapa, Trigo, RS, and the Instituto Biológico de Campinas, SP, Brazil. Isolates were reared in Galleria mellonella (L.) (Lepidoptera: Pyralidae) last-instar larvae, according to the methodology described by Molina and López (2001). Ten G. mellonella larvae were placed in Petri dish ( $9 \mathrm{~cm}$ of diameter), containing two sheets of filter paper and $2 \mathrm{~mL}$ of aqueous suspension at approximately 500 Infective Juveniles (IJs)/mL. Petri dishes were kept for three days in climatic chamber at 25 $\pm 1{ }^{\circ} \mathrm{C}$, with relative humidity (RH) of $70 \pm 10 \%$, and $12 \mathrm{~h}$ photoperiod, when dead larvae and those with symptoms of infection by nematodes were transferred to Petri dishes with filter paper and kept in climatic chamber for five more days.

After this period, larvae were transferred to White trap
(White 1927), and the suspension was taken daily and stored in a Becker containing distilled water and pump for aeration for at the most one week before being used in the tests.

Selection of entomopathogenic nematodes isolates. The nine isolates used for the selection test (Table 1) had been previously reared by the method described by Molina and López (2001). The experiment was carried out in $100 \mathrm{~mL}$ plastic cups containing $7 \mathrm{~g}$ of sterile vermiculite, which had previously received two seeds of corn, and were maintained at room temperature for about a week, until seeds germination.

When plants reached $10 \mathrm{~cm}$, nematodes isolates were quantified and applied over the vermiculite at the concentration of $100 \mathrm{IJ} / \mathrm{cm}^{2}$ (the control treatment received only distilled water), standardizing the percentage of humidity of vermiculite to $20 \%$ (1.4 mL/plastic cup). Afterwards, one of $3^{\text {rd }}$ instar larvae of $A$. ipsilon was put in each cup, totaling 20 larvae per treatment.

Treatments were kept in climatic chamber at $25 \pm 1{ }^{\circ} \mathrm{C}$, $\mathrm{RH}$ of $70 \pm 10$, and 12 hours photoperiod, for five days. After that, the number of dead insects was observed. Dead larvae were dissected under a stereoscopic microscope to confirm mortality by nematodes. The percentage of mortality was calculated in each treatment, considering 20 larvae as $100 \%$.

Tests with immature stages of $\boldsymbol{A}$. ipsilon. Susceptibility at different stages $\left(2^{\text {nd }}, 3^{\text {rd }}, 4^{\text {th }}, 5^{\text {th }}\right.$ and $6^{\text {th }}$ instars and pupae) of $A$. ipsilon was evaluated for the three nematode isolates that presented greater pathogenicity in the selection tests of isolates IBCB-n02 (Steinernema carpocapsae), IBCB-n05 (Heterorhabditis indica) and GL (Heterorhabditis amazonensis).

The test was carried out in $100 \mathrm{~mL}$ plastic cups containing $7 \mathrm{~g}$ of sterile vermiculite, by placing one larva of $A$. ipsilon on the surface together with a piece of diet (modified of Greene et al. 1976) for feeding. Each treatment was replicated four times, and each plot corresponded to ten cups containing one larvae/cup. The pupae were buried into the vermiculite without diet. Afterward, nematode suspension was applied with pipette on the vermiculite surface, at the concentration of $100 \mathrm{IJ} / \mathrm{cm}^{2}$ (only distilled water was used in the control treatment), standardizing humidity to $20 \%$ (1.4 mL/plastic cups).

Cups were kept in climatic chamber at $25 \pm 1{ }^{\circ} \mathrm{C}$, RH 70 \pm 10 , with 12 hours photoperiod, and the test was carried out

Table 1. List of the isolates of entomopathogenic nematodes (genera/species), place of origin, institution and mortality rate caused in Agrotis ipsilon under laboratory conditions.

\begin{tabular}{llllc}
\hline \multicolumn{1}{c}{ Isolates } & \multicolumn{1}{c}{ Genus/ species } & \multicolumn{1}{c}{ LOrigin } & \multicolumn{1}{c}{ Institution } & Mortality (\%) \\
\hline GL & Heterorhabditis amazonensis & Lavras - MG - Brazil & UFLA & 90 \\
RSC05 & Heterorhabditis amazonensis & Benjamin Constant - AM - Brazil & UFLA & 80 \\
JPM4 & Heterorhabditis sp. & Lavras - MG - Brazil & UFLA & 80 \\
CH3 & Steinernema sp. & Campinas - SP - Brazil & Inst. Biológico & 100 \\
IBCB-n02 & Steinernema carpocapsae & Flórida - USA & Inst. Biológico & 90 \\
IBCB-n05 & Heterorhabditis indica & Itapetininga - SP - Brazil & Inst. Biológico & 90 \\
IBCB-n40 & Heterorhabditis sp. & Taboporã - SP - Brazil & Inst. Biológico & 80 \\
IBCB-n44 & Heterorhabditis sp. & Sta. Adélia - SP - Brazil & Inst. Biológico & 80 \\
NEPET11 & Heterorhabditis sp. & Palmeira das Missões - RS - Brazil & Embrapa Trigo & 10 \\
\hline
\end{tabular}


in a completely randomized design, in a factorial scheme 4 $\mathrm{x} 5$, considering three isolates and the control (4), and five instars (5). All data were subjected to homogeneity (Hartley) and normality (Shapiro-Wilk) tests to verify the assumptions of parametric statistics. Data were subjected to analysis of variance (ANOVA), and means were compared by the Tukey test at $5 \%$ probability, using the software SISVAR 5.4 (Ferreira 2011).

Concentrations test. The three isolates that proved to be more virulent to $A$. ipsilon, in the selection test of isolates, were selected (IBCB-n02, IBCB-n05 and GL), using the same methodology of the test with immature stages. However, only $3^{\text {rd }}$ larvae instar was considered, with concentrations of 0 (control treatment), 50, 100, 150, and $200 \mathrm{IJs} / \mathrm{cm}^{2}$.

The test was carried out in completely randomized design, and all data were subjected to homogeneity (Hartley) and normality (Shapiro-Wilk) tests to verify the assumptions of parametric statistics. Data were subjected to analysis of variance (ANOVA) and regression analysis, using the statistical software SISVAR 5.4 (Ferreira 2011) to determine the regression curve and the equation of regression for the interval evaluated in the study.

In vivo production of isolates Steinernema carpocapsae (IBCB-n02), Heterorhabditis indica (IBCB-n05) and Heterorhabditis amazonensis (GL) in A. ipsilon larvae. Plastic Petri dishes ( $9 \mathrm{~cm}$ of diameter) received two filter papers and $10 \mathrm{~A}$. ipsilon larvae, which had been previously weighed. Subsequently, isolates were applied at the concentration of $50 \mathrm{IJS} / \mathrm{cm}^{2}$ in $2 \mathrm{~mL}$ of suspension. Petri dishes were tapped and sealed with PVC film and kept in climatic chamber for 72 hours, at $24 \pm 1{ }^{\circ} \mathrm{C}$, RH of $70 \pm 10$, without photoperiod. After confirmation of mortality, larvae were transferred to new Petri dishes containing only one dry filter paper, and kept for five days under the same conditions. Subsequently, larvae were placed in White traps (one plot per trap). IJs were daily collected in suspension of distilled water and quantified for evaluation of the production. Collection and quantification was repeated until larvae production depletion.

Data were subjected to homogeneity (Hartley) and normality (Shapiro-Wilk) tests to verify the assumptions of parametric statistics. Data were also subjected to analysis of variance and to the Tukey test at $5 \%$ probability, using the software SISVAR 5.4 (Ferreira 2011).

Greenhouse test. For the susceptibility test of $A$. ipsilon under greenhouse conditions, $8 \mathrm{~L}$ cup were prepared with soil, at the ratio of 4:1:0.5 soil, substrate $\left(\right.$ Plantmax $\left.^{\circledR}\right)$ and vermiculite, totaling $2 \mathrm{~L}$ of the mixture of substrates/cup. Five seeds of corn were sown, using the fungicide treatment Maxim XL (fludioxonil $2.5 \%+$ metalaxyl-M 0.1\%) in each plot, and irrigated with $200 \mathrm{~mL}$ water a day.

At 10 days after corn emergency, five $3^{\text {rd }}$ instar $A$. ipsilon larvae were placed in each plot, which were separated into groups of 15 plots/treatment for the application of nematodes isolates (IBCB-n02, IBCB-n05 and GL) in aqueous suspension $\left(100 \mathrm{IJ} / \mathrm{cm}^{2}\right)$ around the plants, using a pipette. Control treatment received only distilled water.

The test was carried out in randomized experimental design. Evaluation occurred at five days after nematodes inoculation, by collecting the dead larvae. Larvae were disinfested with $70 \%$ alcohol and kept in a dry chamber for another three days, when dissection was performed to confirm the death of the insect by the nematode. All data were subjected to homogeneity (Hartley) and normality (ShapiroWilk) tests to verify the assumptions of parametric statistics. Data were subjected to analysis of variance (ANOVA) and the Tukey test at $5 \%$ probability, using the software SISVAR 5.4 (Ferreira 2011).

\section{Results and discussion}

Selection of entomopathogenic nematodes isolates. Isolate $\mathrm{CH} 3$ (Steinernema sp.) presented the highest mortality rate in the selection test $(100 \%)$ (Table 1$)$. However, rearing this isolate in the laboratory is difficult. In other words, the isolate infects and kills $G$. mellonella larvae, but rearing may not occur, which hinders the production of this isolate to be used in nematode tests. Therefore, isolate $\mathrm{CH} 3$ was discarded in subsequent tests.

Other isolates caused between $90 \%$ (IBCB-n02, IBCB-n05, GL) and $80 \%$ of mortality (IBCB-n40, JPM 4, RSC 05 and IBCB-n44), and only the isolate NEPET11 did not cause significant mortality (10\% of mortality) (Table 1$)$.

In relation to susceptibility, Ebssa and Koppenhöfer (2012) tested the isolates Heterorhabditis bacteriophora, $H$. megidis, Steinernema carpocapsae, S. feltiae, S. kraussei, and $S$. riobrave in larvae of $A$. ipsilon, and obtained more than $90 \%$ of mortality, except for $S$. kraussei, which caused only $60 \%$ of mortality. In this work, the present selection test of isolates also reported that most isolates caused more than $80 \%$ of mortality.

This variation of susceptibility for different isolates was expected, since different isolates coevoluted with different species of host, which make them more or less virulent to a determined host (Almenara et al. 2012).

Table 2. Mortality rate of different instars of Agrotis ipsilon after the application of isolates IBCB-n05, GL and IBCB-n02 at the concentration of $100 \mathrm{IJs} / \mathrm{cm}^{2}$ under laboratory conditions. Temperature of $25 \pm 2{ }^{\circ} \mathrm{C}, \mathrm{RH} 70 \pm 10 \%, 12 \mathrm{~h}$ photoperiod.

\begin{tabular}{lccccc}
\hline \multirow{2}{*}{ Treatments } & \multicolumn{5}{c}{ Mortality rate at different instars } \\
\cline { 2 - 5 } & $\mathbf{2}^{\mathbf{0}}$ & $\mathbf{3}^{\mathbf{o}}$ & $\mathbf{4}^{\mathbf{0}}$ & $\mathbf{5}^{\mathbf{0}}$ & $\mathbf{6}^{\mathbf{0}}$ \\
\hline IBCB-n05 & $43 \pm 8.5^{\mathrm{BCa}}$ & $77 \pm 8.5^{\mathrm{Bb}}$ & $83 \pm 6.3^{\mathrm{Bb}}$ & $58 \pm 7.5^{\mathrm{Bab}}$ & $60 \pm 15.8^{\mathrm{Bab}}$ \\
GL & $48 \pm 2.5^{\mathrm{Ca}}$ & $75 \pm 2.9^{\mathrm{Ba}}$ & $80 \pm 5.8^{\mathrm{Ba}}$ & $60 \pm 10.8^{\mathrm{Ba}}$ & $75 \pm 2.9^{\mathrm{Ba}}$ \\
IBCB-n02 & $15 \pm 2.9^{\mathrm{ABa}}$ & $97 \pm 2.5^{\mathrm{Bd}}$ & $83 \pm 8.5^{\mathrm{Bcd}}$ & $50 \pm 4.1^{\mathrm{Bbc}}$ & $45 \pm 8.7^{\mathrm{Bab}}$ \\
Control & $0.0 \pm 0.0^{\mathrm{Aa}}$ & $0.0 \pm 0.0^{\mathrm{Aa}}$ & $0.0 \pm 0.0^{\mathrm{Aa}}$ & $0.0 \pm 0.0^{\mathrm{Aa}}$ & $0.0 \pm 0.0^{\mathrm{Aa}}$ \\
\hline
\end{tabular}

* Means followed by uppercase letters in the columns and lowercase letter in the rows did not significantly differ by the Tukey test $(\mathrm{P} \leq 0.05)$. C.V. 35.59 . 
Tests with immature stages of $\boldsymbol{A}$. ipsilon. The isolates evaluated (IBCB-n05, IBCB-n02 and GL) caused mortality in immature stages of $A$. ipsilon $\left(2^{\text {nd }}, 3^{\text {rd }}, 4^{\text {th }}\right.$, $5^{\text {th }}, 6^{\text {th }}$ instar) with similar values to that observed in the selection test, which was performed just with insects in the $3^{\text {rd }}$ stage (Table 2).

The low mortality in the $2^{\text {nd }}$ instar larvae of $A$. ipsilon may be due to the low metabolic activity of the larvae of young instars and lower movement, since EPNs located their hosts by the concentration of $\mathrm{CO}_{2}$ around them (Nishimatsu and Jacksn 1998). Thus, the low metabolism may have influenced, since it hinders the contact of the nematode with the larvae, which explains the low mortality.

The $3^{\text {rd }}$ and $4^{\text {th }}$ instars presented the highest mortality rate, reaching $97 \%$ in larvae of the $3^{\text {rd }}$ instar and $83 \%$ in larvae of the $4^{\text {rd }}$ for isolate IBCB-n02 ( . carpocapsae). Ebssa and Koppenhöfer (2012) reported similar results in tests with different instars of $A$. ipsilon for the species $S$. carpocapsae, with higher mortality rate for the larvae at the $4^{\text {th }}$ and $5^{\text {th }}$ instars. Conversely, the same authors reported that the $6^{\text {th }}$ instar was less susceptible, differing from the results observed in the present study, in which the lowest mortality rate was obtained in the $2^{\text {rd }}$ instar. Larvae of some Lepidoptera increase susceptibility when they are older; this is because they are bigger, attracting more nematodes, and present more body openings (mouth, anus, and spiracle), making them more susceptible to infective juveniles (Smiths et al. 1994, Shannag et al. 1994). However, in other lepidopteran species, older instars and the pupae are less susceptible (Glazer and Navon 1990; Shannag et al. 1994; Baur et al. 1998). In relation to $A$. ipsilon, according to Ebssa and Koppenhöfer (2012), the reduced body size of the $2^{\text {nd }}$ instar larvae is the main factor for the low mortality rate, since the small size of the larvae makes it difficult for the IJs to access the larvae's body.

Pupae mortality rate observed in the test was not significant for any of the isolates evaluated (5\% for IBCB-n02 and $0 \%$ for IBCB-n05 and GL).

Likewise, in the study developed by Chambers et al. (2010) with Cydia pomonella (Lepidoptera: Tortricidae) (apple moth), the pupae were also less susceptible than the larvae, and in the work of Ebssa and Koppenhöfer (2012), mortality rate of $A$. ipsilon pupae did not surpass $50 \%$, even for the isolates that caused high mortality rate in the larvae.

Among the alternatives proposed for the low susceptibility of $A$. ipsilon pupae, it can be suggested that the lower value of $\mathrm{CO}_{2}$ at this stage may decrease the attraction, or even the displacement the IJ toward the insect (Lewis et al. 1993). In addition, according to Ebssa and Koppenhöfer (2012), A. ipsilon pupae stage occurs in the soil, causing coevolution of this stage together with the EPNs, which could have led to the development of behavioral, physical or physiological defense mechanisms to these entomopathogenic agents.

Concentrations test. All the isolates were pathogenic to $A$. ipsilon at all the concentrations, with mortality rate between 10 and $100 \%$ (Fig. 1). However, mortality data from the isolate GL did not meet the assumptions of normality and homoscedasticity, and therefore were not subjected to regression analysis. Isolate $\mathrm{IBCB}-\mathrm{n} 02$ ( $S$. carpocapsae) showed increasing mortality rate of the larvae stage, according to the increase of the concentration used in the test, and $\mathrm{CL}_{99}$ was estimated at a concentration of $140 \mathrm{IJS} / \mathrm{cm}^{2}$. The isolate IBCB-n05 ( $H$. indica) had $\mathrm{CL}_{99}$ estimated at a concentration of $190 \mathrm{IJs} / \mathrm{cm}^{2}$. For both isolates (IBCB-n02 and IBCB-n05), concentrations can be considered as high. This is confirmed with a study developed by Alves et al. (2017), CL $\mathrm{C}_{99}$ of the isolate CB40 (Heterorhabditis sp.) for G. mellonella was of $9 \mathrm{IJ} / \mathrm{cm}^{2}$. However, G. mellonella is considered as an insect highly susceptible to most entomopathogenic nematode isolates.

In a study developed by Andaló et al. (2010) with Spodoptera frugiperda (Smith, 1797) (Lepidoptera: Noctuidae), the number of IJs to cause maximum mortality was of $223 \mathrm{IJ} /$ /larvae for the isolate RSC02 (Heterorhabditis sp.) and of $218 \mathrm{IJ}$ s/larvae for $S$. arenarium, which are higher values than those observed in this work.

Moreover, according to another study on nematodes for biological control of Lepidoptera, specially $S$. frugiperda, mortality rate of larvae increased with the increase in the concentration (Polanczyk and Alves 2005), corroborating the present results.
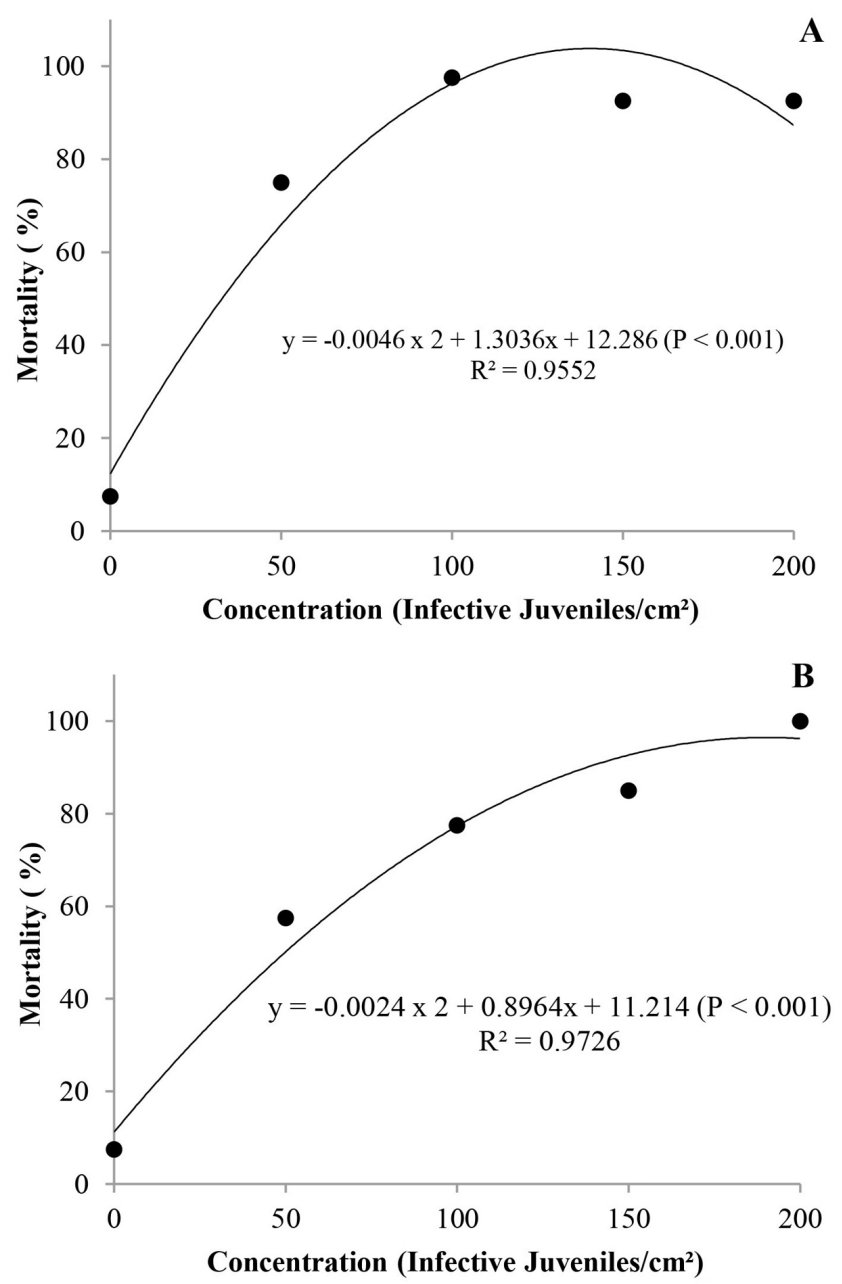

Figure 1. Mortality of Agrotis ipsilon larvae caused by different isolates of entomopathogenic nematodes at different concentrations $\left(\mathrm{IJs} / \mathrm{cm}^{2}\right)$, under laboratory conditions $\left(\mathrm{T}=25 \pm 1{ }^{\circ} \mathrm{C}, \mathrm{RH} 90 \pm 10 \%\right.$, and 12 $\mathrm{h}$ photoeriod). A. IBCB-n02 Steinernema carpocapsae. B. IBCB-n05 Heterorhabditis indica. 
In vivo production of isolates Steinernema carpocapsae (IBCB-n02), Heterorhabditis indica (IBCB-n05) and Heterorhabditis amazonensis (GL) in A. ipsilon larvae. At the end of the production test, the isolates IBCB-n02 (S. carpocapsae), IBCB-n05 ( $H$. indica), and GL $(H$. amazonensis) produced $4.7 \times 10^{-4} \mathrm{IJs} /$ larvae, $2.3 \times 10^{-4} \mathrm{IJs} /$ larvae, and $3.3 \times 10^{-4} \mathrm{IJ} /$ /larvae, respectively. Therefore, no difference was reported between treatments (Table 3 ).

No production tests of EPNs in A. ipsilon have been reported yet. Nevertheless, when compared with production data obtained with $G$. mellonella, the values reported in this work are considered low. Guide et al. (2016) observed that the isolates NEPET11 (Heterorhabditis sp.) and RSC05 (Heterorhabditis amazonensis) presented values of $7 \mathrm{x}$ $10^{-4} \mathrm{IJs} / \mathrm{g}$ larvae and $7.2 \times 10^{-4} \mathrm{IJs} / \mathrm{g}$ larvae, respectively. In addition, Bortoluzzi et al. (2013) evaluated two isolates in G. mellonella and observed $2.2 \times 10^{-5} \mathrm{IJs} / \mathrm{g}$ larvae for CB24 (Heterorhabditis sp.), and $2.2 \times 10^{-5} \mathrm{IJs} / \mathrm{g}$ larvae for CB40 (Heterorhabditis sp.)

Galleria mellonella larvae are susceptible to entomopathogenic nematodes and are frequently used for in vivo production of these nematodes (Gaugler and Han 2002). Conversely, larvae that spend part of their life cycle in contact with the soil, as in the case of $A$. ipsilon, have defense mechanisms against these agents, which can affect the development and reproduction of EPNs in their interior. Thus, Molina et al. (2004) evaluated the production of three nematodes isolates in four different host ( $G$. mellonella, Tenebrio molitor L. (Coleoptera: Tenebrionidae), S. frugiperda and Bombyx mori L. (Lepidoptera: Bombycidae), and observed great difference in production. In addition, Steinernema glaseri did not rear in T. molitor, S. frugiperda and $B$. mori, but it satisfactorily reared in $G$. mellonella. All isolates were able to rear in $A$. ipsilon, suggesting that the insect has mechanisms of resistance that can influence the rearing of the isolates, but cannot prevent EPNs from reproducing inside the larvae.

According to Stuart (2006), there are differences in relation to the virulence of EPNs, which can be attributed to the specificity, morphology, origin, and even the genetic variability of these isolates.

Greenhouse test. The isolate IBCB-n02 reduced the survival rate of the $3^{\text {rd }}$ instar larvae of $A$. ipsilon in the soil. Only this isolate differed from the control treatment under greenhouse conditions (Fig. 2).

During the experiment, larvae caused damage to the corn plants by cutting the stems, at not only in control, but also in the nematodes treatments.

These results can be compared with those obtained by Riga et al. (2001), who tested two isolates of

Table 3. In vivo production of entomopathogenic nematodes (IJs/larvae) in Agrotis ipsilon. Temperature of $25 \pm 2{ }^{\circ} \mathrm{C}, \mathrm{RH} 70 \pm 10 \%$, and $12 \mathrm{~h}$ photoperiod.

\begin{tabular}{lcc}
\hline Isolates & IJs/larvae & Mean weight of larvae \\
\hline IBCB-n02 & $4.7 \times 10^{-4} \pm \mathrm{A}^{*}$ & $0.26 \mathrm{~g}$ \\
IBCB-n05 & $2.3 \times 10^{-4} \mathrm{~A}$ & $0.24 \mathrm{~g}$ \\
$\mathrm{GL}$ & $3.3 \times 10^{-4} \mathrm{~A}$ & $0.28 \mathrm{~g}$ \\
\hline
\end{tabular}

* Means followed by the same uppercase letter in the columns did not significantly differ by the Tukey test $(\mathrm{P} \leq 0.05)$. C.V. 30.95 .

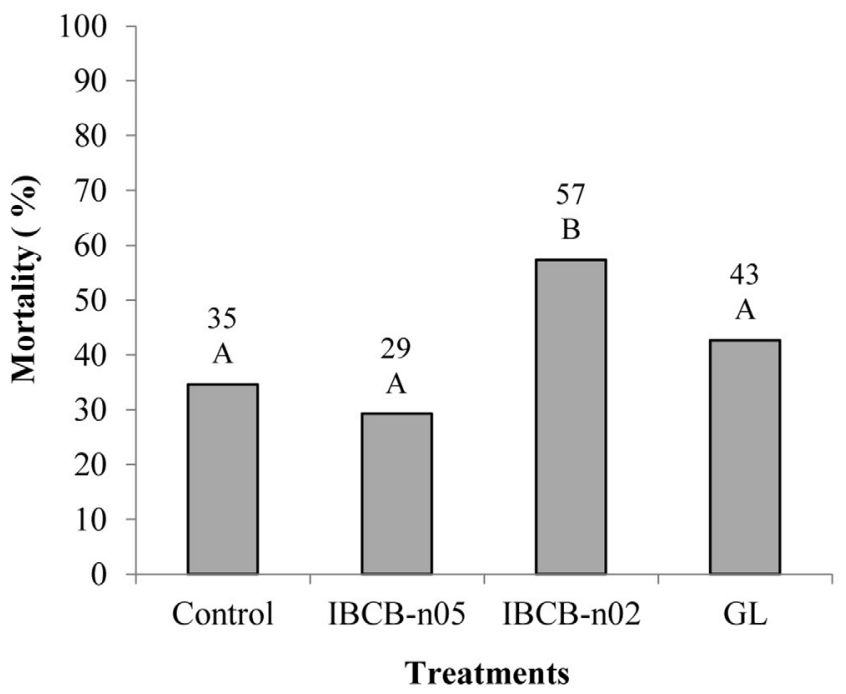

Figure 2. Mortality rate of Agrotis ipsilon larvae caused by different isolates of entomopathogenic nematodes under greenhouse conditions. Columns followed by the same uppercase letter did not significantly differ by the Tukey test $(\mathrm{P} \leq 0.05)$. C.V. 63.24 .

Steinernema against four corn pests, being one of the the noctuidae $S$. frugiperda, under greenhouse conditions. The authors reported that these isolates decreased the damage against corn plants, when compared with the control treatment (without nematode).

In a study developed by Ebssa and Koppenhöfer (2012), the five isolates (H. megidis, H. bacteriophora, S. carpocapsae, $S$. riobrave and $S$. feltiae) caused mortality in $A$. ipsilon under greenhouse conditions, both in larvae at the $3^{\text {rd }}$ and $5^{\text {th }}$ instars. According to the authors, the highest mortality rates were obtained at concentrations of 200IJs/ $\mathrm{cm}^{2}$, which corresponds to twice the concentration used in this work. According to these authors, the time of evaluation was determinant in the mortality rate, and more significant values were observed when the evaluation was carried out at seven days after inoculation.

Factors such as temperature influenced the infectivity of the entomopathogenic nematodes. Moreover, species react differently, i.e., Heterorhabditidae are more sensitive to temperature than Steinernematidae, which might have caused lower mortality rate in the treatment with Heterorhabditis (Flanders et al. 1996).

In the present study, only the isolate IBCB-n02 (v) was able to cause significant mortality in the greenhouse test, which reinforces this statement. Results suggest that this isolate stood out in relation to GL and IBCB-n05, which are of the family Heterorhabditidae.

\section{Conclusion}

The isolate IBCB-n02 (Steinernema carpocapsae) is the most indicated to be used in future studies that aim at $A$. ipsilon control.

\section{Acknowledgements}

To Fundação Araucária for the financial support for the Project, and to Conselho Nacional de Desenvolvimento Científico e Tecnológico (CNPq), for the scholarship granted. 


\section{Literature cited}

ALMENARA, D. P.; ROSSI, C.; NEVES, M. R. C.; WINTER, C. E. 2012. Nematoides entomopatogênicos cap. 16. pp. 1-40. In: Silva-Neto, M. A. C.; Winter, C.; Termignoni, C. (Org.). Tópicos avançados em Entomologia Molecular. Instituto Nacional de Ciência e Tecnologia em Entomologia Molecular INCT-EM, São Paulo.

ALVES, V. S.; ALVES, L. F. A.; QUADROS, J. C.; LEITE, L. G. 2009. Susceptibility of borer-yerba-mate Hedypathes betulinus (Klug, 1825) (Coleoptera: Cebrambycidae) the nematode Steinernema carpocapsae (Nematoda, Steinernematidae). Arquivos do Instituto Biológico 76: 479-482.

ALVES, V. S.; NEVES, P. M. J. O.; ALVES, L. F. A.; MOINO JUNIOR, A.; HOLZ, N. 2012. Entomopathogenic nematodes (Rhabditida: Heterorhabditidae and Steinernematidae) screening for lesse rmeal worm Alphitobius diaperinus (Coleoptera: Tenebrionidae) control. Revista Colombiana de Entomologia 38: 76-80.

ALVES, V. S.; ALVES, L. F. A.; FANTI, A. L.; ALVES, M. 2017. Potential of entomopathogenic nematodes for controlo of the erva-mate pest Hedypathes betulinus (Klug, 1825) (Coleoptera: Cerambycidae). Floresta 47: 113-120.

ANDALÓ, V.; SANTOS, V.; MOREIRA, G. F.; MOREIRA, C. C.; MOINO JUNIOR, A. 2010. Evaluation of entomopathogenic nematodes under laboratory and greenhouse conditions for the control of Spodoptera frugiperda. Ciência Rural 40: 18601866.

ANDALÓ, V.; SANTOS, V.; MOREIRA, G. F.; MOREIRA, C.; FREIRE, M.; MOINO JUNIOR, A. 2012. Movement of Heterorhabditis amazonesis and Steinernema arenarium in search of corn fall army worm larvae in artificial conditions. Scientia Agricola 69: 226-230.

BAUR, M. E.; KAYA, H. K.; TABASHNIK, B. 1998. Supression of diamondback moth (Lepidoptera: Plutellidae) with an entomopathogenic nematode (Rhabdita: Steinernematidae) and Baccilus thuringiensis Berliner. Journal of Economic Entomology 91: 1089-1095.

BENTO, F. M. M.; MAGRO, S. R.; FORTES, P.; ZÉRIO, N. G.; PARRA, J. R. P. 2007. Biologia e tabela de vida de fertilidade de Agrotis ipsilon em dieta artificial. Pesquisa Agropecuária Brasileira 42: 1369-1372.

BORTOLUZZI, L.; ALVES, L. F. A.; ALVES, V. S.; HOLZ, N. 2013. Entomopathogenic nematodes and their interaction with chemical insecticide aiming at the control of banana weevil borer, Cosmopolites sordidus (Coleoptera: Curculionidae). Arquivos do Instituto Biológico 80: 183-192.

CHAMBERS, U.; BRUCK, D. J.; OLSEN, J.; WALTON, V. M. 2010. Control of overwintering fibertworm (Lepidoptera: Tortricidae) larvae with Steinernema carpocapsae. Journal of Economical Entomology 103: 416-422.

EBSSA, L.; KOPPENHÖFER, A. M. 2012. Entomopathogenic nematodes for the management of Agrotis ipsilon: effect of instar, nematode species and nematode production method. Society of Chemical Industry 68: 947-957.

FERNANDES, F. L.; DINIZ, J. F. S.; SILVA, P. R.; MOSCA, E. 2013. Damage of Agrotis ipsilon (Lepidoptera: Noctuidae) on Coffea arabica in Brazil. Revista Colombiana de Entomología 39: 49-50.

FERRAZ, L. C. C. B. 1998. Entomopathogenic nematodes. pp. 541-570. In: Alves, S. B. (Ed.). Microbial control of insects. FEALQ Piracicaba, São Paulo. 1163 p.

FERREIRA, D. F. 2011. SISVAR: A computer statistical analysis system. Ciência e Agrotecnologia 35: 1039-1042.

FLANDERS, K. L.; MILLER, J. M. SHIELDS, E. J. 1996. In vivo production of Heterorhabditis bacteriophora Oswego (Rhabditida: Heterorhabditidae), a potential biological control agent for soil-inhabiting insects in temperate regions. Journal of Economic Entomology 89: 373-380.
GAUGLER, R.; HAN, R. 2002. Production technology. pp. 289310. In: Gaugler, R. (Ed.). Entomopathogenic nematology. New Jersey: Rutgers University.

GLAZER, I; NAVON, A. 1990. Activity and persistence of entomopathogenic nematodes tested against Heliothis armigera (Lepidoptera: Noctuidae). Journal of Economic Entomology 83: 1795-1800.

GUIDE, B. A.; SOARES, E. A.; ITIMURA, C. B.; ALVES, V. S. 2016. Entomopathogenic nematodes in the control of cassava root mealybug Dysmicoccus sp. (Hemiptera: Pseudococcidae). Revista Colombiana de Entomología 42: 16-21.

GREENE, G. L.; LEPLA, N. C.; DICKERSON, W. A. 1976. Velvetbean caterpillar: a rearing procedure and artificial medium. Journal of Economic Entomology 69: 488-497.

GREWAL, P. S.; NARDO, E. A. B. DE; AGUILLERA, M. 2001. Entomopathogenic nematodes: Potential for exploration and use in South America. Neotropical Entomology 30: 191-205.

KULLIK, S. G.; SEARS, M. K.; SCHAAFSMA, A. W. 2011. Sub- lethal effects of Cry1F Bt corn and clothianidin on black cutworm (Lepidoptera: Noctuidae) larval development. Journal of Economic Entomology 104: 484-493.

LEITE, L. G.; TAVARES, F. M.; GOULART, R. M.; BATISTA FILHO, A.; PARRA, J. R. P. 2005. Pathogenicity of the entomopathogenic nematode larvae of $6^{\circ}$ instar of, Ecdytolopha aurantiana (Lepidoptera: Tortricidae), and evaluating dosages of Heterorhabditis indica insect mortality. Revista de Agricultura 80: 316-330.

LEWIS, E. E.; GAUGLER, R.; HARISSON, R. 1993. Response of cruiser and ambusher entomopathogenic nematodes (Steinernematidae) to host volatile cues. Canadian Journal Zoology 71: 765-769.

LEWIS, E. D.; CAMPBELL, J.; GRIFFIN, C.; KAYA, H.; PETERS, A. 2006. Behavioral ecology of entomopathogenic nematodes. Biological Control 38: 66-79.

LINK, D.; COSTA, E. C. 1984. Comportamento larval da lagartarosca, Agrotis ipsilon (Hufnagel, 1767). Revista Centro de Ciências Rurais 14: 191-199.

LINK, D.; PEDROLO, S. S. 1987. Aspectos biológicos de Agrotis ipsilon (Hufnagel, 1767). Santa Maria - RS. Revista de Ciências Rurais 17: 309-317.

MACHADO, L. A.; HABIB, M.; LEITE, L. G.; CALEGARI, L. C.; GOULART, R. M.; TAVARES, F. M. 2005. Pathogenicity of the entomopathogenic nematode eggs and larva of Migdolus fryanus (Westwood, 1863) (Coleoptera: Vesperidae). Arquivos do Instituto Biológico 72: 221-226.

MENEZES, R. S.; DUMAS, V. F.; MARTINS, E. S.; PRAÇA, L. B.; MONNERAT, R. G. 2010. Seleção e caracterização de estirpes de Bacillus thuringiensis tóxicas a Agrotis ipsilon. Universitas: Ciências da Saúde 8: 1-13.

MOLINA, J. P.; LÓPEZ, N. J. C. 2001. In vivo production of entomopathogenic nematodes infection with two sets of two hosts. Revista Colombiana de Entomología 27: 73-78.

MOLINA, J. P. A.; MOINO JR., A.; CAVALCANTI, R. S. 2004. Produção in vivo de nematoides entomopatogênicos em diferentes insetos hospedeiros. Arquivos do Instituto Biológico 71: 347-354.

POINAR, G. O. 1990. Biology and taxonomy of Steinernematidae. pp. 23-31. In: Gaugler, R. R.; Kaya, H. K. Entomopathogenic nematodes in biological control. CRC Press, Boca Raton.

POLANCZYK, R. A.; ALVES, S. B. 2005. Interaction between Bacillus thuringiensis and other entomopathogens to control Spodoptera frugiperda. Manejo Integrado de Plagas y Agroecología 74: 24-33.

PRATER, C. A.; REDMOND, C. T.; BARNEY, W.; BONNING, B. C.; POTTER, D. A. 2006. Microbial control of Black Cutworm (Lepidoptera: Noctuidae) in turfgrass using Agrotis ipsilon multiple nucleopolyhedrovirus. Journal of Economic Entomology 99: 1129-1137. 
REESE, J. C.; BECK, S. D. 1976. Effects of allelochemics on the black cutworm, Agrotis ipsilon; Effects of p-benzoquinone, hydroquinone and duroquinone on larval growth, development and utilization of food. Annals of the Entomological Society of America 69: 59-67.

RIGA, E.; WHISTlECRAFT, J.; POTTER, J. 2001. Potential of controlling insect pests of corn using entomopathogenic nematodes. Canadian Journal of Plant Science 81: 783-787.

SALVADORI, J. M. 2011. Caracterização da patogenicidade de nematoides entomopatogênicos e de bactérias associadas para o controle biológico de Spodoptera frugiperda (Lepidoptera: Noctuidae). Porto Alegre: Universidade Federal do Rio Grande do Sul. 140 p. Thesis (Biologia Celular e Molecular).

SHANNAG, H. K.; WEBB, S. E.; CAPINERA, J. L. 1994. Entomopathogenic nematode effect on pickleworm (Lepidoptera: Pyralidae) under laboratory and field conditions. Journal of Economic Entomology 87: 1205-1212.

SMITHS, P. H.; WIEGERS, G. L.; VLUG, H. J. 1994. Selection of insect parasitic nematodes for biological control of the garden chafer, Phyllopertha horticola. Entomologia Experimentalis et Applicata 70: 77-82.
STUART, R. J. 2006. Population biology of entomopathogenic nematodes: concepts, issues, and models. Biological Control 38: 80-102.

TOLEDO, A. V.; REMESLENICOV, A. M; LOPEZ-LASTRA, C. C. 2010. Histopathology cause by the entomopathogenic fungi, Bauveria bassiana and Metarhizium anisopliae, in the adult planthopper, Peregrinus maidis, a maize virus vector. Journal of Insect Science 10: 1-10.

WHITE, G. F. 1927. A method for obtaining infective nematode larvae from cultures. Science 66: 302-303.

Received: 12-Jan-2017 • Accepted: 24-Mar-2018

Suggested citation:

GIANNASI, A. O.; BRAMBILA, C. R.; ZART, M.; GUIDE, B. A.; ALVES, V. S. 2018. Assessment of entomopathogenic nematodes in Agrotis ipsilon (Lepidoptera: Noctuidae) under laboratory and greenhouse conditions. Revista Colombiana de Entomología 44 (1): 25-31. Enero - Junio 2018. 